Original Research Paper

\title{
The Motility and Ratio of $X$ and Y Sperm Filial Ongole Cattle Using Different Sexed Semen Methods
}

\author{
${ }^{1}$ Enike Dwi Kusumawati, ${ }^{2}$ N. Isnaini, ${ }^{2}$ A.P.A. Yekti, ${ }^{3}$ M. Luthfi, ${ }^{3}$ L. Affandhy, ${ }^{3}$ D. Pamungkas, \\ ${ }^{2}$ Kuswati, ${ }^{2}$ A. Ridhowi, ${ }^{2}$ H. Sudarwati, ${ }^{4}$ Syam Rahadi, ${ }^{5}$ S. Rahayu and ${ }^{2}$ Trinil Susilawati \\ ${ }^{1}$ Animal Husbandry Faculty, Universitas Kanjuruhan Malang, Malang, Indonesia \\ ${ }^{2}$ Animal Husbandry Faculty, Brawijaya University, Malang, Indonesia \\ ${ }^{3}$ Beef Cattle Research Station, Pasuruan, Indonesia \\ ${ }^{4}$ Animal Science Faculty, Universitas Halu Oleo, Kendari, Indonesia \\ ${ }^{5}$ Biology Department Faculty of Mathematics and Natural Sciences, Brawijaya University, Malang, Indonesia
}

Article history

Received: 22-03-2018

Revised: 25-10-2018

Accepted: 09-02-2019

Corresponding Author:

Enike Dwi Kusumawati,

Animal Husbandry Faculty,

Universitas Kanjuruhan

Malang, Jl. S. Supriadi No 48

Malang, Indonesia

Email: enike@unikama.ac.id

\begin{abstract}
Artificial Insemination (AI) using sexed semen produce sex of calf as expected. There are various methods of sexed semen has been found. The aim of this research is to determine the effect of sexed semen methods using egg white sedimentation and percoll density gradient centrifugation toward motility and ratio of $\mathrm{X}$ and $\mathrm{Y}$ sperm Filial Ongole Cattle. Semen was collected using Artificial Vagina (AV) from Filial Ongole Cattle, evaluated and then separated using egg white sedimentation and percoll density gradient centrifugation technique. Only fresh semen with a minimum of $70 \%$ individual motile sperm and 2+ mass motility used in this study. Andromed as a based extender was diluted using aquabidest with 1:4 ratio. The obtained data were analyzed with analysis of variance (ANOVA) and continued by Duncan test if there was significant or very significant different. The result showed that the sexing methods (non sexing sperm, upper and under fraction using percoll density gradient centrifugation, upper and under fraction using egg white sedimentation technique) had very significant effect $(\mathrm{P}<0.01)$ on motility $(64.25 \pm 3.94 \% ; 48.55 \pm 8.28 \% ; 53 \pm 7.93 \% ; 56.9 \pm 8.22 \% ; 49.75 \pm 8.19 \%$ respectively) and significant effect $(\mathrm{P}<0.05)$ on the ratio of $\mathrm{X}$ and $\mathrm{Y}$ sperm. The ratio of $\mathrm{X}$ and $\mathrm{Y}$ using percoll density gradient centrifugation and egg white sedimentation methods for the upper fraction were $28.0 \pm 2.26 \%: 72.0 \pm 2.26 \%$ and $77.5 \pm 1.26 \%: 22.5 \pm 1.26 \%$. The ratio of $X$ and $Y$ using percoll density gradient centrifugation and egg white sedimentation technique for the under fraction were $69.0 \pm 15.35 \%: 26.0 \pm 4.37 \%$ and $22.9 \pm 1.44 \%: 77.1 \pm 1.44 \%$. The study concludes that the sexed with egg white sedimentation technique is better than percoll density gradient centrifugation on sperm motility and ratio of $\mathrm{X}$ and $\mathrm{Y}$ sperm.
\end{abstract}

Keywords: Separation, Methods, Sexed, Sperm Quality, Sperm Proportion

\section{Introduction}

The Effort to increase the efficiency of using AI in cattle is how to obtain the effectiveness of sperm separation (sexed semen) technology to separate $\mathrm{X}$ and $\mathrm{Y}$ sperm chromosomes (Kusumawati et al., 2015; Saili et al., 2017). There are various methods of sexed semen has been found including the sedimentation method using albumin column and percoll density gradient centrifugation (Hafez and Hafez, 2008). Motility is an important indicator for characterization of sperm quality after processing. Sexing methods easily applied is Egg White Sedimentation (EWS)
(Afiati, 2004; Saili et al., 2017) and Percoll Density Gradient Centrifugation method (PDGC). Percoll is a medium that can be made with various densities and does not penetrate cell membrane (Susilawati, 2014). Although sexed sperm is currently used, the high cost and the reduced pregnancy rates compared to conventional sperm (Carvalho et al., 2014). Therefore it is necessary to look for alternative other ingredients as a substitute of egg whites and to determine the effect of sexed semen methods using egg white sedimentation and percoll density gradient centrifugation toward motility and ratio of $\mathrm{X}$ and $\mathrm{Y}$ sperm Filial Ongole Cattle. 


\section{Materials and Methods}

Semen was collected using AV from five Filial Ongole Cattle in Beef Cattle Research Station, Pasuruan, Indonesia. After collection, fresh semen was evaluated macroscopically (colour, $\mathrm{pH}$, volume) and microscopically (concentration, mass motility, individual motility, sperm viability and sperm abnormality). Only fresh semen with a minimum of $70 \%$ individual motile sperm and $2+$ mass motility used in this study. Semen collection was regularly conducted twice a week.

The selected semen separated using egg white sedimentation (Kusumawati et al., 2017) and percoll density gradient centrifugation technique. $\mathrm{X}$ and $\mathrm{Y}$ sperm separation method using egg whites sedimentation with 3 densities $(10 \%, 30 \%$ and $50 \%)$ made from highest to lowest density (Purwoistri et al., 2013) and incubated for $20 \mathrm{~min}$. Separation method using 10 density percoll with 10 arranged from highest to lowest density $(65 \%$, $60 \%, 55 \%, 50 \%, 45 \%, 40 \%, 35 \%, 30 \%, 25 \%, 20 \%$ ) and centrifuged at $2250 \mathrm{rpm}$ for $5 \mathrm{~min}$ (Susilawati, 2014). Andromed as a based extender was diluted using aquabidest with 1:4 ratio. The experiment was designed using completely random design with 3 treatment (non sexing, percoll density gradient centrifugation, egg white sedimentation methods) and 10 replication.

The parameters observed, percentage of $\mathrm{X}$ and $\mathrm{Y}$ sperm based on morphometry of sperm wide head, percentage of motility before and after separation of the sexed semen. The obtained data were analyzed with analysis of variance (ANOVA) and continued by Duncan test if there was significant or very significant different.

\section{Results}

The semen samples from Filial Ongole Cattle used in this study were evaluated both macroscopic and microscopically. The characteristics of 10 ejaculates used in this study such as volume, color, $\mathrm{pH}$, consistency, mass motility, progressive motility, viability, abnormality, concentration were $4.4 \pm 2.18 \mathrm{~mL}$, creamy, $7 \pm 0$, thick, $2+, \quad 70 \pm 0 \%, \quad 95.12 \pm 0.98 \%$, $0.92 \pm 0.27 \%, \quad 1,758 \pm 137.66 \times 106 / \mathrm{ml}$, respectively. The morphometry observation of the fresh semen, showed that the percentage of $\mathrm{X}$ and $\mathrm{Y}$ sperm approaching

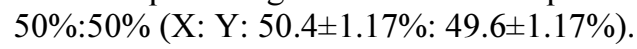

Motility and abnormality percentage of Filial Ongole Cattle sexed semen with different methods is shown in Table 1. X and Y sperm ratio of Filial Ongole Cattle sexed semen with different methods shown in Table 2.

\section{Discussion}

\section{Characteristic of Fresh Filial Ongole Cattle Semen}

The semen used in this study was normal (Garner and Hafez, 2008; Ax et al., 2008; Pineda, 2003). The morphometry observation of the fresh semen is in accordance with the general state of the $\mathrm{X}$ and $\mathrm{Y}$ sperm ratio in the fresh semen is $50 \%: 50 \%$ and after fertilization, $50 \%$ the embryo should be males and $50 \%$ should be females (Pineda, 2003). The cattle were used in this study has a standard percentage motility of $70 \%$ and no more than $70 \%$, this corresponds to Ax et al. (2008) found a decent standard of sperm in the further process was $70 \%$. If the percentage motility of sperms that have below $60 \%$ the results will not meet the standards in the process before freezing up in the freezing process. The viability was $95.12 \pm 0.98 \%$ which was still within in the normal range or more than $80 \%$ (Susilawati et al., 2014). The abnormalities $0.92 \pm 0.27 \%$ was less than $20 \%$ (Ax et al., 2008). Semen concentration values obtained in this study is $1.758 \pm 137.66 \times 106 / \mathrm{mL}$ which shows that the value of the concentration of relatively normal because, according to Garner and Hafez (2008) sperm concentration of cattle is $800-2000 \times 106 / \mathrm{ml}$. Examination of the concentration needs to be done because the sperm concentration can be used to predict the fertility of cattle (Ax et al., 2008). The quality of fresh semen used in this study was the semen that has good quality, it was intended that the sperms were able to survive during the separation process.

\section{Motility and Abnormality of Filial Ongole Cattle Sexed Semen}

The result in Table 1 shows that the sperm motility was highly significant different $(\mathrm{P}<0.01)$ after sexing between sexing methods. The sperm motility of egg white sedimentation (Upper Fraction) sexed semen was better than other treatments and no different from non sexing method (control). The sperm motility of percoll density gradient centrifugation is lower than egg white sedimentation. This is because the centrifugation causes more damage the sperm membrane (Kusumawati et al., 2017). Furthermore, sperm motility will decline as an increase in the number of the broken membrane (Kusumawati and Leondro, 2015; Sekosi et al., 2016; Kusumawati et al., 2016).

Table 1: Motility and abnormality percentage of Filial Ongole Cattle sexed semen with different methods

\begin{tabular}{lll}
\hline Sexing methods & Motility (\%) & Abnormality (\%) \\
\hline Non Sexing (control) & $64 \pm 3.94^{\mathrm{b}}$ & $0.93 \pm 0.28^{\mathrm{a}}$ \\
PDGC (Upper Fraction) & $48 \pm 8.28^{\mathrm{a}}$ & $1.98 \pm 0.27^{\mathrm{b}}$ \\
PDGC (Under Fraction) & $53 \pm 7.93^{\mathrm{a}}$ & $4.42 \pm 0.36^{\mathrm{d}}$ \\
EWS (Upper Fraction) & $57 \pm 8.23^{\mathrm{b}}$ & $2.27 \pm 0.36^{\mathrm{b}}$ \\
EWS (Under Fraction) & $50 \pm 8.19^{\mathrm{a}}$ & $3.38 \pm 1.00^{\mathrm{c}}$ \\
\hline
\end{tabular}

a,b,c,d different superscripts in column indicate highly significant different $(\mathrm{P}<0,01)$ 
Table 2: $\mathrm{X}$ and $\mathrm{Y}$ sperm ratio of Filial Ongole Cattle sexed semen with different methods

\begin{tabular}{lll} 
& X and Y sperm ratio (\%) & \\
Sexing Methods & $-\mathrm{X}$ sperm & Y sperm \\
\hline Non Sexing & $50.4 \pm 1.17 \%$ & $49.6 \pm 1.17 \%$ \\
PDGC (Upper Fraction) & $280 \pm 2.26 \%$ & $72.0 \pm 2.26 \%$ \\
PDGC (Under Fraction) & $775 \pm 1.26 \%$ & $22.5 \pm 1.26 \%$ \\
EWS (Upper Fraction) & $690 \pm 15.35 \%$ & $26.0 \pm 4.37 \%$ \\
EWS (Under Fraction) & $229 \pm 1.44 \%$ & $77.1 \pm 1.44 \%$ \\
\hline
\end{tabular}

The sperm must have less than $25 \%$ major morphologic abnormalities (Pineda, 2003) or more than $80 \%$ of the sperm conform to normal morphology (Ax et al., 2008). Susilawati et al. (2014) found that centrifugation process might also damage the sperm membrane, thus causing a decrease in sperm motility. The centrifugation process provided free radicals namely Reactive Oxygen Species (ROS) that damaged the sperm membrane (Zanella et al., 2016). ROS are free radicals that play a crucial role in many sperm physiological processes such as capacitating, hyperactivation and spermoocytes fusion (Aitken et al., 2012; Ball, 2008; Bansal and Bilaspuri, 2011). The minimum standard post thawing motility is $25 \%$ (Pineda, 2003).

\section{$X$ and $Y$ Sperm Ratio of Filial Ongole Cattle Sexed Semen}

The result in Table 2 shows the significant effect $(\mathrm{P}<0,05)$ on the ratio of $\mathrm{X}$ and $\mathrm{Y}$ sperm sexed semen between sexing methods. The sexed semen with egg white sedimentation method is better than percoll density gradient centrifugation on the ratio of $\mathrm{X}$ and $\mathrm{Y}$ sperm. Under fraction have a high of $X$ sperms, whereas the upper fraction have a high of $\mathrm{Y}$ sperms on percoll density gradient centrifugation method. The sexed semen with egg white sedimentation method produces a high of $X$ sperms on upper fraction, whereas the under fraction have a high of $\mathrm{Y}$ sperms. From all of the research results, sexing sperm technology using egg white sedimentation technique is better than percoll density gradient centrifugation on the ratio of $\mathrm{X}$ and $\mathrm{Y}$ sperm.

\section{Conclusion}

The study concludes that the sexed with egg white sedimentation technique is better than percoll density gradient centrifugation on sperm motility and abnormality.

\section{Acknowledgment}

Beef Cattle Research Station which has allowed implementation of research.

\section{Funding Information}

Ministry of Finance through Indonesia's Endowment Fund for Education (LPDP) which has provided research funding (Contract Number?).

\section{Author's Contributions}

Enike Dwi Kusumawati and Trinil Susailawati: Designed and coordinated the study.

N. Isnaini: Completed data entry.

A.P.A. Yekti: Completed management.

M. Luthfi, L. Affandhy and D. Pamungkas: Bulls maintenance management

A. Ridhowi, H. Sudarwati and Syam Rahadi: Analysis and drafted the manuscript.

Syam Rahadi and S. Rahayu: Facilitated the edited the manuscript.

\section{Ethics}

A this survey was approved by the Brawijaya University and Universitas Kanjuruhan Malang.

\section{References}

Afiati, F., 2004. Proporsi dan karakteristik spermatozoa $\mathrm{X}$ dan $\mathrm{Y}$ hasil separasi kolom albumin. Media Peternakan, 27: 16-20.

Aitken, R.J., K.T. Jones and S.A. Robertson, 2012. Reactive Oxygen Species and Review Sperm Function-In Stickness and In Health. J. Androl., 22: 1096-1106. DOI: 10.2164/jandrol.112.016535

Ax, R.L., M.R. Dally, B.A. Didion, R.W. Lenz and C.C. Love et al., 2008. Artifical Ainsemination. In: Reproduction in Farm Animals, Hafez, E.S.E. and B. Hafez, (Eds.). Australia: Blackwell Publishing, ISBN: 978-0-6833-0577-7, pp: 365-375.

Ball, B.A., 2008. Oxidative stress, osmotic stress and apoptosis: impact on sperm function and preservation in the horse. Animal Reproduction Sci., 107: 257-267.

DOI: 10.1016/j.anireprosci.2008.04.014

Bansal, A.K. and G.S. Bilaspuri, 2011. Impacts of oxidative stress and antioxidants on semen functions. Vet. Medicine Int.., 2011: 1-7. DOI: $10.4061 / 2011 / 686137$ 
Carvalho, J.O., R. Sartori and M.A.N. Dode, 2014. Different ways to evaluate bovine sexed sperm in vitro. Anim. Reprod, 11: 199-206.

Garner, D.L. and E.S.E. Hafez, 2008. Spermatozoa and Seminal Plasma. In: Reproduction in Farm Animals, Hafez E.S.E. and B. Hafez (Eds.), Australia: Blackwell Publishing, ISBN-10: 978-0-6833-0577-7, pp: 96-109.

Hafez, E.S.E. and B. Hafez, 2008. $X$ and $Y$ Chromosome-Bearing Spermatozoa. In: Reproduction in Farm Animals, Hafez, E.S.E. and B. Hafez, (Eds.), Australia: Blackwell Publishing, ISBN: 978-0-6833-0577-7, pp: 390-394.

Kusumawati, E.D. and H. Leondro, 2015. The quality of fresh semen of bulls at $5^{\circ} \mathrm{C}$ and $24^{\circ} \mathrm{C}$ with or without Diluent. Proceedings International Seminar Improving Tropical Animal Production Food Security, 1: 122-126.

Kusumawati, E.D., H. Leondro, A.T.N. Krisnaningsih, T. Susilawati and N. Isnaini et al., 2016. Pengaruh suhu dan lama simpan semen segar terhadap motilitas dan abnormalitas spermatozoa kambing Peranakan Etawa (PE). Seminar Nasional Hasil Penelitian, 4: 199-208.

Kusumawati, E.D., H. Leondro, T. Susilawati and N. Isnaini, 2015. Spermatozoa viability of filial Ettawa goat after sexing process. Proceeding International Seminar Improving Tropical Animal Production Food Security, 1: 127-130.

Kusumawati, E.D., N. Isnaini, A.P.A. Yekti, M. Luthfi and L. Affandhy et al., 2017. The quality of sexed semen on filial ongole bull using percoll density gradient centrifugation method. Asian J. Microbiol. Biotechnol. Environ. Sci. Paper, 19: 199-203.
Pineda, M.H., 2003. The Biology of Sex. In: McDonal's. Veterinary Endocrinology and Reproduction. 5th Edn., USA: Blackwell Publishing. ISBN-13: 978-0-8138-1106-2/2007, pp: 201-238.

Purwoistri, R.F., T. Susilawati and S. Rahayu, 2013. Membran spermatozoa hasil seksing gradien albumin berpengencer andromed dan cauda epididymal plasma-2 ditambahkan kuning telur. J. Vet., 14: 371-378.

Saili, T., L.O.B. La Ode Nafiu, S. Rahadi, A. Napirah and I.W. Sura et al., 2017. Efektivitas Sinkronisasi Estrus dan Fertilitas Spermatozoa Hasil Sexing pada Sapi Bali di Sulawesi Tenggara. J. Vet. September, 18: 1-7. DOI: 10.19087/jveteriner.2017.18.3.353

Sekosi, P.P.P., E.D. Kusumawati, A.T.N. Krisnaningsih, 2016. Motilitas dan viabilitas semen segar kambing Peranakan Etawa (PE) Dengan Menggunakan Pengencer Cauda Epididymal Plasma (CEP-2) pada lama dan suhu simpan yang berbeda. J. Sains Peternakan, 4: 34-49.

Susilawati, T., 2014. Sexing Spermatozoa (Hasil Penelitian Laboratorium dan Aplikasi pada Sapi dan Kambing). Malang: Universitas Brawijaya Press, ISBN-10: 978-602-203-711-8.

Susilawati, T., R. Sri, U. Setyabudi, S. Herni and N. Eko, 2014. Effect of different centrifugation on simmental bull sperm quality and membrane status after sexing, cooling and freezing processes. Am. Eurasian J. Sustainable Agric., 8: 28-34.

Zanella, E., R. Zanella, M.R. Poetini, M.G. Marques and J.C.M. Soares et al., 2016. Oxidative status of boar semen during storage. Am. J. Biochem. Biotechnol., 12: 95-101. DOI: 10.3844/ajbbsp.2016.95.101 